\title{
Identification of hepatitis B virus genotypes in the state of São Paulo
}

Ana Paula de Torres Santos ${ }^{1,2}$, José Eduardo Levi ${ }^{3}$, Marcílio Figueiredo Lemos ${ }^{1}$, Samira Julien Calux ${ }^{1}$, Isabel Takano Oba ${ }^{1}$, Regina Célia Moreira ${ }^{1 *}$

${ }^{1}$ Center for Blood and Sexually Transmitted Diseases, Adolfo Lutz Institute, São Paulo, SP, Brazil

2Laboratory of Immunology of the Central Laboratory Department at Hospital das Clínicas, Faculty of Medicine, University of São Paulo (USP), São Paulo, SP, Brazil

3Virology Laboratory of the Institute of Tropical Medicine, USP, São Paulo, SP, Brazil

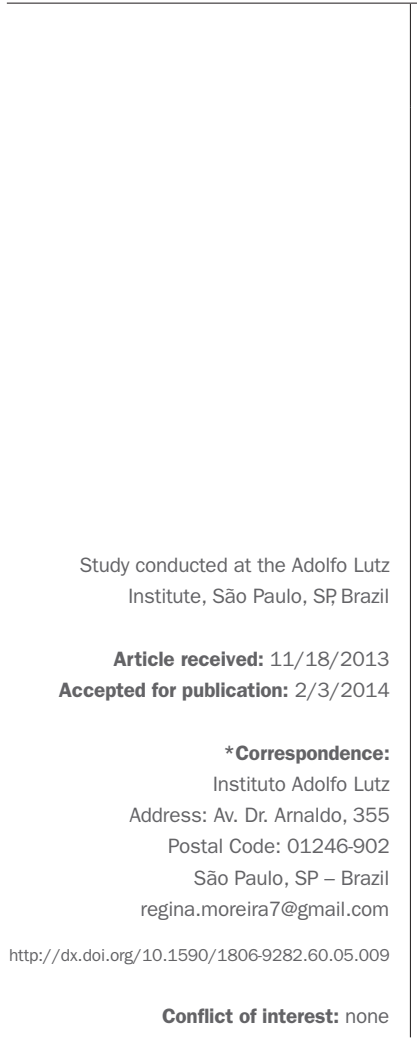

\section{SUMMARY}

Objective: the aim of this study was to identify HBV genotypes in serum samples from patients from the state of São Paulo, received by the viral hepatitis laboratory, at the Virology Centre of Instituto Adolfo Lutz, from various municipalities.

Methods: a total of 94 serum samples were randomly analyzed. Genotyping was performed using nested PCR for amplification of S and Pol regions from viral genome. Genotypes were identified comparing the sequences obtained with the sequences deposited in GenBank.

Results: we were able to determine the genotype of 91 (97\%) samples, as follows: genotype A (55.3\%), D (32\%), F (5.3\%), C (3.2\%) and G (1\%). There are few data on the epidemiology of genotype $\mathrm{G}$. This genotype has been detected in restricted areas around the world. Frequently, the genotype G infection occurs in HIV-positive male patients. In our case, the sample identified as $\mathrm{G}$ was also positive for HIV but in a female patient, which is an uncommon finding in the scientific literature.

Conclusion: in this work, we identified the most frequent genotypes in São Paulo as well as the genotype G, rare among the genotypes found in our environment.

Keywords: hepatitis B, polymerase chain reaction, genotype, Brazil.

\section{INTRODUCTION}

Hepatitis caused by the hepatitis B virus (HBV) is a disease of great importance to public health around the world. Approximately $30 \%$ of the world's population, or about 2 billion people, have serologic evidence of current or past infection with HBV. Of these, it is estimated that approximately 360 million people are chronically infected and 600,000 die every year due to acute severe hepatitis, hepatocellular carcinoma or cirrhosis. ${ }^{1}$

HBV has ten distinct genotypes (A to J), identified and defined according to a difference of $8 \%$ in their genomic sequences. Recent studies suggest that HBV genotypes may differentially affect the severity of liver diseases such as cirrhosis and hepatocellular carcinoma, as well as response to treatment. ${ }^{2}$ The HBV genotypes have distinct geographical distribution. Genotype A is found mainly in North America and Africa. Genotypes B and C are prevalent in Southeast Asia and the Far East, and the latter has been associated with increased risk of hepatocellular carcinoma. Genotype D has been found throughout the world with the highest prevalence in the Mediterranean, Middle East, South Asia and particularly in India. Genotypes $\mathrm{E}$ and $\mathrm{F}$ are prevalent in West Africa and Brazil's indigenous population, respectively. Moreover, genotype $\mathrm{G}$ has been reported in the USA, France, Colombia and Brazil while genotype $\mathrm{H}$ has been found in North and Central America. Recently, through phylogenetic analysis, a new genotype was characterized in Vietnam and Laos, being designated as genotype I, ${ }^{3,4}$ while genotype J was identified in Japan. ${ }^{5}$ In Brazil, the most common genotype is $\mathrm{A}$, followed by genotypes $\mathrm{D}$ and $\mathrm{F}$. 
The North, Northeast and Southeast regions have a higher frequency of genotype A, while genotype D is the most common in the South. ${ }^{6}$ In some regions, genotypes B and $\mathrm{C}$ are also detected at low prevalence, reflecting the presence of descendants of Asian immigrants in these populations. ${ }^{7}$ A study conducted in Ribeirão Preto, São Paulo, found genotype $\mathrm{D}$ in $56.5 \%$ of the cases, genotype $\mathrm{A}$ in $41.3 \%$, and genotype in $2.2 \%{ }^{8}$ The presence of these genotypes reflects the mix of cultures in Brazil: Native American, European and African backgrounds make the country an important model for studies of population genetics, suggesting an influence of the immigration pattern in each region. ${ }^{9}$

The aim of this study was to identify HBV genotypes in samples received by the viral hepatitis at the Adolfo Lutz Institute, for determining HBV viral load.

\section{Methods}

\section{Sampling}

During this study, samples from chronic carriers of HBV patients, treated by Public Health Services in the state of São Paulo, were analyzed in order to initiate or monitor treatment. Clinical follow-up and laboratory diagnosis of these patients were performed using commercial tests available throughout Brazil, approved and regulated by the National Health Surveillance Agency (Anvisa) of the Ministry of Health.

The sample consisted of 94 plasma specimens from patients from health centers and public hospitals in the state of São Paulo, in the period comprising June 2010 to May 2011. The samples were stored in a freezer at $-20^{\circ} \mathrm{C}$ and thawed immediately before testing.

\section{DNA extraction}

Extraction of HBV DNA was carried out using the commercial kit QIAamp ${ }^{\circledR}$ DNA Mini and Blood Mini Handbook - QIAGEN®, as described in the manufacturer's instructions. ${ }^{6}$

\section{Polymerase chain reaction}

The polymerase chain reaction (PCR) was performed as described by Kaneko et al. ${ }^{10,11}$ with some modifications. The $\mathrm{S}$ and Pol regions were amplified according to the protocol reported by Sitnik et al., ${ }^{7}$ for subsequent identification of the HBV genotypes.

\section{Sequencing}

To determine the genotypes, we used the product amplified by Nested-PCR of S and Pol regions of HBV. The positive samples were sequenced using ABI Prism BigDyeTM
Terminator V.3.0 kit. The genotypes were confirmed using the genotyping tool available from the NCBI website (http://www.ncbi.nlm.nih.gov/projects/genotyping/formpage.cgi).

\section{Results}

Of all the samples analyzed, 50 were from females and 44 from male patients, ages ranged from 1 to 71 years with a median of 40 years. All 94 samples extracted and analyzed by PCR tested positive. Through sequencing, we were able to determine the genotypes of 91 samples (97\%) (Figure 1) and genotypes were: A (55.3\%), D (32\%), F (5.3\%), $\mathrm{C}(3.2 \%)$ and $\mathrm{G}(1 \%)$. To confirm the sample identified as genotype $\mathrm{G}$, another extraction, PCR and sequencing were performed.

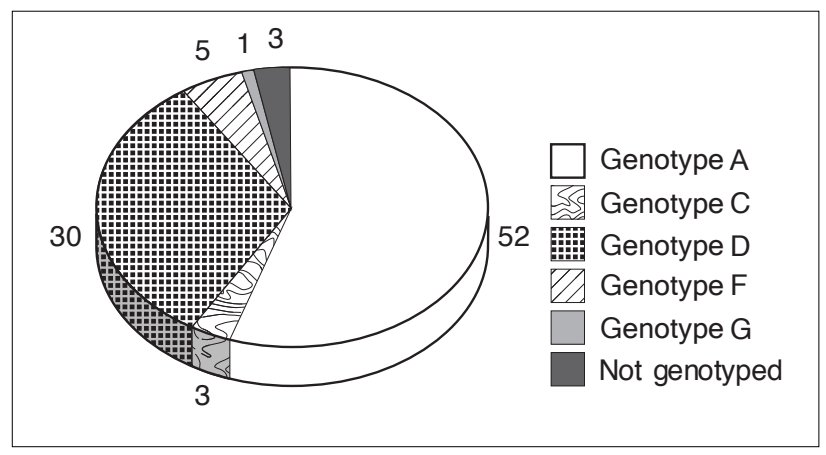

FIGURE 1 Distribution of the HBV genotypes identified in samples collected in the state of São Paulo. ${ }^{2}$

\section{Discussion}

HBV genotyping may be an important tool for prognosis of disease progression and treatment. Furthermore, it may be important for understanding the evolution and epidemiology of the virus, since the genotypes vary according to geographic region and often correlated with risk factors.

As expected, the most prevalent genotypes in the study population were genotypes $\mathrm{A}$ and $\mathrm{D}$, and these results are consistent with studies on the prevalence of genotypes in Brazil. Genotypes A and D are the most prevalent worldwide, while genotype $\mathrm{F}$ is prevalent in the Americas and genotype $\mathrm{C}$ is characteristic of the Asian population; genotype $\mathrm{C}$ is also quite common in the state of São Paulo. Compri et al. ${ }^{12}$ found genotypes A, D and C in children, adolescents and their families in the state of São Paulo. Moraes et al. ${ }^{13}$ found genotypes A, D and F in Rio de Janeiro. These same genotypes were also described in populations in Goiânia and Santa Catarina. ${ }^{14,15,16}$

Recent studies have suggested that the rate of lamivudine resistance was higher in patients infected with HBV ge- 
notype A than those with genotype D. ${ }^{17,18}$ Genotype C has been associated with lower rates of spontaneous clearance of HBeAg in serum compared to infection with genotype $B$. In addition, genotype $\mathrm{C}$ is associated with higher levels of HBV DNA replication, more advanced liver disease, hepatocellular carcinoma, and a decreased rate of response to interferon treatment compared with genotype B. ${ }^{19}$

A strain of genotype $G$, which is not common in our population, was also identified in this study. The genotype $\mathrm{G}$ sample came from a female patient carrying the human immunodeficiency virus (HIV). Bottecchia et al. ${ }^{20}$ identified the genotype $\mathrm{G}$ in a patient infected with HBV and in only two patients coinfected with HIV. The presence of genotype $\mathrm{G}$ has been associated with sexual relations between men. ${ }^{21} \mathrm{~A}$ study conducted by Sanchez et al..$^{22}$ showed a high prevalence of genotype $\mathrm{G}$ only in men who have sex with men (MSM) and always coinfected with another genotype of HBV. In Brazil, Silva et al. ${ }^{23}$ identified two patients with genotype $G$ in this population which could somehow be associated with this sexual behavior.

Genotype $\mathrm{G}$ was first described in $2000 .{ }^{24}$ Later, this genotype was also identified in the United States, Canada, Brazil, Mexico, France, Germany, Vietnam, Thailand, and Japan. ${ }^{21,25,26}$ Genotype $G$ is essentially identical to the other HBV genotypes, but has some unique features including an insertion of $36 \mathrm{bp}$ at the gene start codon. ${ }^{24}$ Genotype $\mathrm{G}$ is the rarest of all HBV genotypes. This genotype is usually found as a coinfection with other HBV genotypes. ${ }^{26}$ Work conducted by Bottecchia et al. ${ }^{20}$ demonstrated that patients with HBV genotype G presented lamivudine-resistance mutations and large genetic variation among samples, which points out the importance of the circulation of genotype $\mathrm{G}$ in Brazil for the treatment of HBV. Nevertheless, epidemiological and clinical data are still limited, probably due to the low incidence worldwide.

Among the approximately 40 million people infected with HIV worldwide, an estimated two million to four million are also chronically infected with HBV. ${ }^{27}$ The prevalence rates of HIV/HBV coinfection, obtained in Brazilian studies of samples from health services, are between $5.3 \%$ and $24.3 \%$. The increased incidence of chronic complications of viral hepatitis in this population has been observed, which differs from what is seen with other opportunistic diseases. This is explained by increased survival of HIV-infected patients from the use of antiretrovirals. In general, HBV infection tends to be more aggressive in HIV-infected individuals than in mono-infected patients, with highest rates of HBV carriers, higher
HBV viremia levels, more frequent episodes of activation and more rapid progression to cirrhosis. ${ }^{27}$

The identification and determination of epidemiology and molecular characteristics of circulating HBV genotypes is important and can be a tool for prognosis and treatment of HBV as well as the hepatitis C virus (HCV). Furthermore, it demonstrates the circulation of different viral strains in Brazil. Clinical follow-up of individuals with chronic HBV infection should be one of the concerns, making it necessary to implement continuous measures of prevention-based health education. The most effective measure to combat HBV infection is active immunization of susceptible individuals, using currently available vaccines, which are highly efficient and safe, in addition to encouraging the use of condoms, and spreading information on the risk presented by manicures and drug users. These measures enable the creation of programs for infection control, seeking eventual eradication of hepatitis B and prophylaxis of hepatocellular carcinoma. ${ }^{28}$

\section{Conclusion}

In this study, we identify the HBV genotypes prevalent in the state of São Paulo. Genotypes identified are those already described in previous studies, and we also found a sample infected with genotype $\mathrm{G}$, a rare genotype, associated with men who have sex with other men, HIV-positive. However, in our study, genotype $G$ was found in a female HIV-infected patient, which demonstrates the relevance and need of genotyping a larger number of patients. Genotyping is an important tool for prognosis of disease progression, treatment, and better understanding of the virus' evolution and epidemiology, since genotypes vary according to geographical regions and often correlate with risk factors.

Project approved on 9/29/2009 by the Research Ethics Committee of the Adolfo Lutz Institute - CEPIAL (CCD-BM 06/2009), according to Resolution 196/96 on research involving human subjects, published by the National Health Council - Ministry of Health - Brasília (1996).

Project $n^{\circ} 09 / 53086-42$, financed by the FAPESP.

\section{Resumo}

Identificação dos genótipos do vírus da hepatite B no Estado de São Paulo.

Objetivo: o objetivo deste estudo foi identificar os genótipos do HBV nas amostras de soros recebidas pelo Laboratório de Hepatites do Centro de Virologia do Instituto Adolfo Lutz. 
Métodos: foram analisadas aleatoriamente 94 amostras de soropositivas, provenientes de diversos municípios do Estado de São Paulo. Para determinação dos genótipos, foi realizada Nested-PCR das regiões S e Pol do HBV. Os genótipos foram identificados comparando os resultados amplificados com as sequências depositadas no GenBank. Resultados: foi possível determinar o genótipo de 91 (97\%) amostras do total analisado e os genótipos identificados foram: genótipos A (55,3\%), D (32\%), F (5,3\%), C (3,2\%) e $\mathrm{G}(1 \%)$. Há poucos dados a respeito da epidemiologia do genótipo G. Esse genótipo tem sido detectado em áreas restritas do mundo. Geralmente, a infecção pelo genótipo $\mathrm{G}$ ocorre em indivíduos HIV positivos do sexo masculino. Neste trabalho, a amostra identificada como G foi também positiva para HIV e era de uma paciente do sexo feminino, dado raro na literatura científica.

Conclusão: neste trabalho, foram identificados os genótipos mais frequentes, assim como uma cepa do genótipo $\mathrm{G}$, rara entre os encontrados em nosso meio.

Palavras-chave: hepatite B; reação em cadeia da polimerase; genótipo; Brasil.

\section{RefERENCES}

1. Valla DC. Easl international consensus conference on hepatitis B. J Hepatol. 2003;38:533-40.

2. Sunbul M, Lebleisbicioglu H. Distribuition of hepatitis B virus genotypes in patitents with chronics hepatitis B in Turey. World J Gastroenterol. 2005;11(13):1976-80

3. Yu H, Yuan Q, Ge SX, Wang HY, Zhang YL, Chen QR, Zhang J, Chen PJ, Xia NS. Molecular and phylogenetic analyses suggest an additional hepatitis B virus genotype "I". PLoS One. 2010; 5:e9297.

4. Alvarado-Mora MV, Botelho L, Gomes-Gouvêa MS, Souza VF, Nascimento MC, Pannuti CS, et al. Detection of Hepatitis B virus subgenotype A1 in a Quilombo community from Maranhão, Brazil. Virol J. 2011;8:415.

5. Jia-Horng Kao. Molecular Epidemiology of Hepatitis B Virus. Korean J Intern Med. 2011;26(3):255-61.

6. Mello FC, Souto FJ, Nabuco LC, Villela-Nogueira CA, Coelho HS, Franz $\mathrm{HC}$, et al. Hepatitis B virus genotypes circulating in Brazil: molecular characterization of genotype F isolates. BMC Microbiol. 2007;7:103.

7. Sitnik R, Pinho JR, Bertolini DA, Bernardini AP, Da Silva LC, Carrilho FJ. Hepatitis B virus genotypes and precore and core mutants in Brazilian patients. J Clin Microbiol. 2004;42:2455-60.

8. Rezende RE, Fonseca BAL, Ramalho LNZ, Zucoloto S, Pinho JRR, Bertolini $\mathrm{DA}$, et al. The precore mutation is associated with severity of liver damage in Brazilian patients with chronic hepatitis. J Clin Virol. 2005; 32:53-9.

9. Alcalde R, Melo FL, Nishiya A, Ferreira SC, Langhi Junior MD, Fernandes SS, et al. Distribution of hepatitis B virus genotypes and viral load levels in Brazilian chronically infected patients in Sao Paulo city. Rev Inst Med Trop São Paulo. 2009;51:269-72.

10. Kaneko S, Feinstone SM, Miller RH. Rapid and sensitive method for the detection of serum hepatitis B virus DNA using the polymerase chain reaction technique. J Clin Microbiol. 1989; 27:1930-3.
11. Kaneko S, Miller RH, Feinstone SM, Unoura M, Kobayashi K, Hattori N, et al. Detection of serum hepatitis B virus DNA in patients with chronic hepatitis using the polymerase chain reaction assay. Proc Natl Acad Sci USA. 1989;86:312-6

12. Compri AP, Miura I, Porta G, Lemos MF, Saraceni CP, Moreira RC. Hepatitis $B$ virus infection in children, adolescents, and their relatives: genotype distribution and precore and core gene mutations. Rev Soc Bras Med Trop. 2012;45:301-4.

13. Moraes MT, Gomes AS, Niel C. Sequence analysis of the pre-S/S gene of hepatitis B virus strains genotypes A, D and F isolated in Brazil. Arch Virol.1996;114:1767-73.

14. Teles SA, Martins RM, Vanderborght B, Stuyer L, Gaspar AM, Yoshida CF. Hepatitis B virus: genotypes and subtypes in Brazilian hemodialysis patients. Artif Organs. 1999;23:1074-8.

15. Carrilho FJ, Moraes CR, Pinho JRR, Moreira RC, Bertolini DA, Mello IM, et al. Hepatitis B virus infection in haemodialysis centers from Santa Catarina State, Southern Brazil: predictive factors for infection and molecular epidemiology. BMC Public Health. 2004;04:13 AM.

16. Viana S, Paraná R, Moreira RC, Compri AP, Macedo V. High prevalence of hepatitis B virus and hepatitis D virus in the Western Brazilian Amazon. Am J Trop Med Hyg. 2005;73:808-14.

17. Kobayashi M, Suzuki F, Akuta N, Suzuki Y, Arase Y, Ikeda K, et al. Response to long-term lamivudine treatment in patients 12 infected with hepatitis B virus genotypes A, B, and C. J Med Virol. 2006;78(10):1276-83.

18. Orito E, Fujiwara K, Tanaka Y, Yuen MF, Lai CL, Kato T, et al. A case-control study of response to lamivudine therapy for 2 years in Japanese and Chinese patients chronically infected with hepatitis $\mathrm{B}$ virus of genotypes $\mathrm{Bj}, \mathrm{Ba}$ and C. Hepatol Res. 2006;35:127-34.

19. Yang HI, Yeh SH, Chen PJ, Iloeje UH, Jen CL, Su J, et al.; Reveal-HBV Study Group. Between Hepatitis B virus genotype and mutants and the risk of hepatocellular carcinoma. J Natl Cancer Inst. 2008;100:1134-43.

20. Bottecchia M, Souto FJ, Kycia MR Ó, Amendola M, Brandão CE, Niel C, et al. Hepatitis B virus genotypes and resistance mutations in patients under long term lamivudine therapy: characterization of genotype $\mathrm{G}$ in Brazil. BMC Microbiol. 2008;08:11 AM.

21. Sanchez LV, Maldonado M, Bastidas-Ramirez BE, Norder H, Panduro A. Genotypes and S-gene variability of Mexican hepatitis B virus strains. J Med Virol.2002;68:24-32.

22. Sánchez LV, Tanaka Y, Maldonado M, Mizokami M, Panduro A. Difference of hepatitis B virus genotype distribution in two groups of mexican patients with different risk factors. High prevalence of genotype H and G. Intervirology. 2007;50:9-15.

23. Silva AC, Spina AM, Lemos MF, Oba IT, Guastini CF, Gomes-Gouvêa MS, et al. Hepatitis B genotype $\mathrm{G}$ and high frequency of lamivudine-resistance mutations among human immunodeficiency virus/hepatitis B virus coinfected patients in Brazil. Mem Inst Oswaldo Cruz. 2010; 105:770-8.

24. Stuyver L, De Gendt S, Van Geyt C, Zoulim F, Fried M, Schinazi RF, et al. A new genotype of hepatitis B virus: complete genome and phylogenetic relatedness. J Gen Virol. 2000;81:67-74.

25. Vieth S, Manegold C, Drosten C, Nippraschk T, Gunther S. Sequence and phylogenetic analysis of hepatitis B virus genotype $\mathrm{G}$ isolated in Germany. Virus Genes. 2002; 24:153-6.

26. Osiowy C, Gordon D, Borlang J, Giles E, Villeneuve JP. Hepatitis B virus genotype $\mathrm{G}$ epidemiology and co-infection with genotype A in Canada. J Gen Virol. 2008; 89:3009-15.

27. Ranjbar R, Davari A, Izadi M, Jonaidi N, Alavian SM. HIV/HBV co-infections: epidemiology, natural history, and treatment: a review article. Iran Red Crescent Med J. 2011;13:855-62.

28. Osti C, Marcondes-Machado J. Vírus da hepatite B: avaliação da resposta sorológica à vacina em funcionários de limpeza de hospital-escola. Ciênc Saúde Coletiva. 2010;03:01 PM. 